Raf. J. Sci.,Vol.28, No.2 Special Issue for the Third Scientific Conference of Chemistry, pp.204-210, 2019

\title{
Preparation and Physico Chemical Investigation of Manganese (II) Complexes with Hydrazone Ligands
}

\author{
*Sahbaa A. Ahmed \\ Department of Chemistry/ College of Science/ University of Mosul \\ **Amira J. Al-Shaheen \\ Department of Chemistry/ College of Education for Pure Science/ University of Mosul \\ ** E-mail: Sahbaa.ali@gmail.com *E-mail: a.inorganic@yahoo.com
}

(Received 25/9/2018; Accepted 25/10/2018)

\begin{abstract}
The work reported deals with the preparation and characterization of a number of new complexes of manganese (II). The complexes are formed by the reaction of the mentioned metal salts with three ligands of Schiff base type; the ligands are: dibenzoinlidenemalonoyldihydrazide $\left(\mathrm{L}_{1} \mathrm{H}_{4}\right)$, dibenzoinlidenesuccinyldihydrazide $\left(\mathrm{L}_{2} \mathrm{H}_{4}\right)$ and dibenzoinlidenephthalolyldihydrazide $\left(\mathrm{L}_{3} \mathrm{H}_{4}\right)$. The prepared complexes have been characterized by molar conductance, $\mathrm{CHN}$ analysis, metal contents,electronic spectra, infrared spectra, and magnetic susceptibility measurements. The different studies suggest that all the complexes are hexacoordinated with octahedral geometry in the neutral medium; the ligands formed cationic complexes of the type $\left[\mathrm{Mn}\left(\mathrm{LH}_{4}\right)\right] \mathrm{X}_{2}$ were $\mathrm{X}=\mathrm{Cl}^{-1}$ and $\mathrm{NO}_{3}{ }^{-1}$, while in a basic medium anionic complexes of the general formula $\mathrm{K}_{2}[\mathrm{Mn}(\mathrm{L})]$.
\end{abstract}

Keywords: Acid hydrazide, Hydrazone ligands, Schiff base complexes, Manganese (II) complexes.

\section{تحضير ورلسة المزليا الفيزوكيميلئية لمقدات المنغنيز(II) مع ليكندات الهيرازونات}

\section{الملخص}

مـ في هذا البمث تحضير وتشخيص عدد من المعقدات الجيدة للمنغنيز(II) حضرت المعقدات الناتجة من تقاعل الأملاح

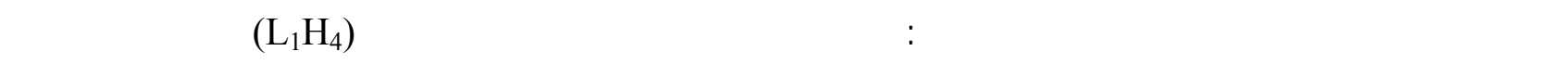
سكسناليل ثنائي هيدرازيد ققنيت مختلفة فيزوكيمياوية وطفية مختلفة مل القيلست التوصيلية المولارية، التحليل الدقيق للعناصر الفلزي، قيلست الطيف الالكترونية،طيف الأثعة تحت الحمراء والقيلست المغنلطيسية. ولستنتج من هذه الدرلسلت ان كل

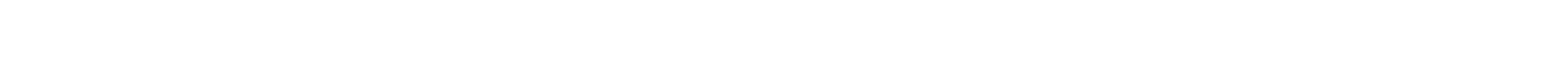
المتعالل ايونية موجبة لها الصيغة العلمة اليونيةسالبة ذات الصيغة العلمة

الكاملت الدالة : حلمض الهيدرازيد، ليكندات الهيدرازون، معقدات قواعشيف،معقدات المنغنيز الثنائية.

INTRODUCTION

The coordination chemistry of hydrazones and their metal complexes have gained importance because of their use as a model for biological system. In addition, they are known to exhibit a wide variety of pharmacological properties such as analgesic, antinflammatory, antimalarial, 
antithelmentic activity, antitubercular, hypotensive actions, xantitumor, anticonvulsant, and carcinostatic activity (Singh and Singh, 2013; Jang et al., 2005; Sallomi et al., 2011; Al-Shaheen et al., 2012; Al-Shaheen et al., 2013; Al-Shaheen et al., 2017). Biological ctivities of hydrazone metal complexes are also reported for several transitional metals (Bernhardt et al.,2008; Alagesan et al., 2013; Sathyadevi et al., 2012). Recently, considerable attention has been paid to chemistry of the metal complexes of Schiff bases containing oxygen, nitrogen and other donors because they offer many attractive properties such as displaying a double role of electron transport and light emission, higher thermal stability and easy sublimation (Saydam and Alkan, 2001; Ciobanu et al., 2006; Sone and Fukuda, 1987). Schiff bases derived from the reaction of the aldehydes or ketones with hydrazides are very interesting since they are present in keto-enol forms and can form different types of complexes (Suresh and Prakash, 2011; Feng et al., 2009; Wageih and Moawaad, 2001). In present work, new manganese complexes are formed with ligands derived from benzoin and malonyl dihydrazide $\left(\mathrm{L}_{1} \mathrm{H}_{4}\right)$, succinyldihydrazide $\left(\mathrm{L}_{2} \mathrm{H}_{4}\right)$ and phthalolyldihydrazide $\left(\mathrm{L}_{3} \mathrm{H}_{4}\right)$, (Scheme 1) have been synthesized and are characterized by different chemical, physical and spectral methods.

\section{Material and Measurement}

\section{EXPERIMENTAL}

All the chemicals used were supplied from Fluka, BDH, Aldrich, Merck, Acid hydrazides, malonyl, succinyl and phthaloyl dihydrazides were prepared by the condensation of the corresponding esters and hydrazine hydrate in 1:2 molar ratio according to the reported procedure (Baker et al., 1950). Manganese contents were determined by atomic absorption method, CHN analyzer type vector, mode 1 E.A 3000 v.3.0 single Euro.in College of Pure Science/ University of Baghdad. Electronic spectra were recorded on Shimadzu UV-160 spectrophotometer for $10^{-3} \mathrm{M}$ for complexes in DMF at $25^{\circ} \mathrm{C}$ using $1 \mathrm{~cm}$ quartz cell. Infrared absorption was recorded on a Perkin-Elmer 580 spectrophotometer as $\mathrm{KBr}$ Pelletes in the range $400-4000 \mathrm{~cm}^{-1}$. Molar conductance of the complexes was measured at room temperature for $10^{-3} \mathrm{M}$ in DMF solution using conductivity bridge type LF-42. Magnetic susceptibility of the complexes was measured by BrukerBM6.

\section{Preparation of Hydrazone}

These were prepared according to the literature method (Baker et al., 1950) by reacting to a solution of acid dihydrazide $(0.01 \mathrm{~mole}, 1.43 \mathrm{~g})$ malonyldihydrazide (MDH2) or $(0.01 \mathrm{~mole}, 1.50 \mathrm{~g})$ succinyldihydrazide $\left(\mathrm{SDH}_{2}\right)$ or $(0.01$ mole, $2.15 \mathrm{~g})$ phthaloyldihydrazide $\left.(\mathrm{PDH} 2)\right]$ in ethanol $20 \mathrm{ml}$ was add to the solution of benzoin $(0.02 \mathrm{~mole}, 4.70 \mathrm{~g})$ in ethanol. The reaction mixture was heated under reflux for 3-9 hrs. After cooling, fine precipitate was formed which was filtered off, washed with cold ethanol and dried in oven at $70-80{ }^{\circ} \mathrm{C}$.

\section{Preparation of the Metal Complexes}

In order to the metal complexes (1:1 molar ratio, manganese salts: ligand), a general procedure has been used for the preparation of the complexes in neutral and basic medium. In neutral medium a solution of $(0.001$ mole, $0.125 \mathrm{~g})$ of manganese chloride or $(0.001$ mole, $0.178 \mathrm{~g})$ manganese nitrate in $10 \mathrm{ml}$ of ethanol has been added to the solution of one of acid dihydrazides $\left[\mathrm{L}_{1} \mathrm{H}_{4}\right.$ (0.001 mole, $0.520 \mathrm{~g})$ or $\mathrm{L}_{2} \mathrm{H}_{4}(0.001$ mole, $0.534 \mathrm{~g})$ or $\mathrm{L}_{3} \mathrm{H}_{4}(0.001$ mole, $\left.0.582 \mathrm{~g})\right]$. An ethanolic mixture containing manganese (II) salt and the ligand has been refluxed for about three hours. After cooling, the separated complexes were filtered off, recrystallized from hot water and dried. The alkaline medium complexes have been prepared by applying the same above amounts except that the ligands were treated with $1 \mathrm{M} \mathrm{KOH}$ solution. Complete precipitation of the complexes were achieved at $\mathrm{pH} 9-10$. The mixtures were left to stand for 30 minutes, then filtered off, recrystallized from hot water and dried in oven at $70-80{ }^{\circ} \mathrm{C}$. 


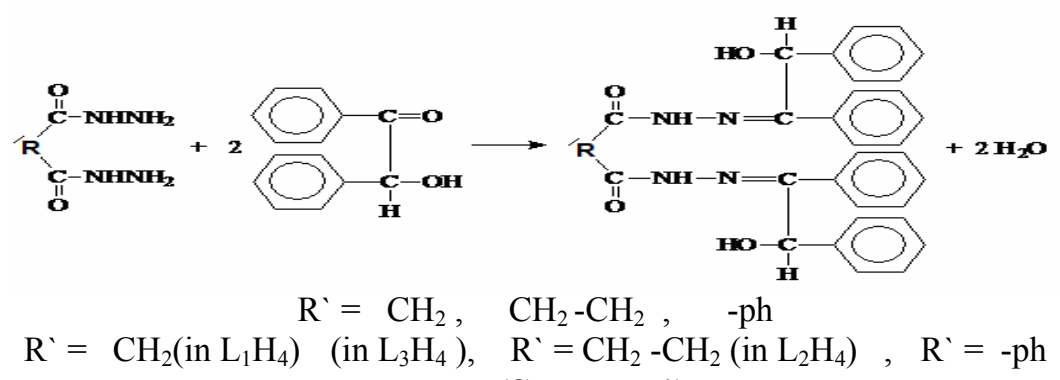

(Scheme 1)

Preparation of ligand, $\left(\mathrm{L}_{1} \mathrm{H}_{4}\right),\left(\mathrm{L}_{2} \mathrm{H}_{4}\right),\left(\mathrm{L}_{3} \mathrm{H}_{4}\right)$

\section{RESULTS AND DISCUSSION}

The reaction of benzoin and acid dihydrazide in ethanol gave the desired hydrazone ligand $\left(\mathrm{L}_{1} \mathrm{H}_{4}\right),\left(\mathrm{L}_{2} \mathrm{H}_{4}\right),\left(\mathrm{L}_{3} \mathrm{H}_{4}\right)($ Scheme 1) in excellent yield and purity. The analytical data and some of the physical properties of the prepared ligand and its complexes are shown in (Table 1) which indicates that metal chlorides and metal nitrate form 1:1 (M:L) complexes with general formula, $\left[\mathrm{M}\left(\mathrm{LH}_{4}\right)\right] \mathrm{X}_{2}$ and $\mathrm{K}_{2}[\mathrm{M}(\mathrm{L})]$. For all the complexes, the metal contents and the molar conductance values are in a good agreement with the given formulations as shown (Table 1). The solid complexes are colored, and conductance in DMF (Sallomi and Al-Shaheen, 1994; Despaigne et al., 2009; Chohan et al.,

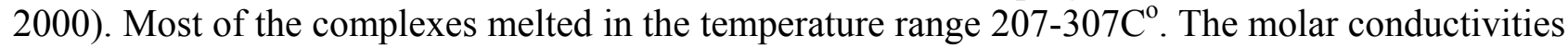
of the complexes in DMF indicated the presence of two types of complexes, a molar conductance data of $10^{-3} \mathrm{M}$ solutions of the complexes (Table 1) at room temperature which show values (110188) $\mathrm{ohm}^{-1} . \mathrm{cm}^{2} . \mathrm{mol}^{-1}$ indicating that they are $1: 2$ electrolytes in the neutral medium, while in the basic medium as 2:1 electrolytes. (Geary, 1971).

Table 1: Some physical and analysis data of the ligand and their complexes

\begin{tabular}{|c|c|c|c|c|c|c|c|c|}
\hline \multirow{2}{*}{$\begin{array}{c}\text { No. of } \\
\text { Complexes }\end{array}$} & \multirow{2}{*}{ Formula } & \multirow{2}{*}{ Color } & \multirow{2}{*}{$\begin{array}{l}\text { M.P. } \\
\left(C^{0}\right)\end{array}$} & \multirow{2}{*}{$\begin{array}{c}\Lambda_{\mathrm{M}} \text { DMF } \\
\mathrm{Ohm}^{-1} \cdot \mathrm{Cm}^{2} \cdot \mathrm{mol}^{-1}\end{array}$} & \multirow{2}{*}{$\begin{array}{c}\text { \% Mn } \\
\text { analysis } \\
\text { Calc. (obser) }\end{array}$} & \multicolumn{3}{|c|}{$\begin{array}{l}\text { \% anal ysis, } \\
\text { Calc. (obser) }\end{array}$} \\
\hline & & & & & & $\mathrm{C}$ & $\mathrm{H}$ & $\mathrm{N}$ \\
\hline & $\mathrm{L}_{1} \mathrm{H}_{4}$ & Yellow & 150 & & & $\begin{array}{l}71.53 \\
7041\end{array}$ & $\begin{array}{l}5.38 \\
522\end{array}$ & $\begin{array}{l}10.7 \\
956\end{array}$ \\
\hline 1 & {$\left[\mathrm{Mn}\left(\mathrm{L}_{1} \mathrm{H}_{4}\right)\right] \mathrm{Cl}_{2}$} & Yellow & 207 & 147 & $\begin{array}{l}8.51 \\
8.85\end{array}$ & $\begin{array}{l}57.58 \\
57.63\end{array}$ & $\begin{array}{l}4.33 \\
2.60\end{array}$ & $\begin{array}{c}8.668 . \\
91\end{array}$ \\
\hline 2 & $\mathrm{~K}_{2}\left[\mathrm{Mn}\left(\mathrm{L}_{1}\right)\right]$ & Dark Yellow & 232 & 110 & $\begin{array}{l}8.47 \\
8.67\end{array}$ & $\begin{array}{l}57.31 \\
50.04\end{array}$ & $\begin{array}{l}3.69 \\
3.72\end{array}$ & $\begin{array}{c}8.627 . \\
55 .\end{array}$ \\
\hline 3 & $\begin{array}{c}{\left[\mathrm{Mn}\left(\mathrm{L}_{1} \mathrm{H}_{4}\right)\right]\left(\mathrm{NO}_{3}\right)} \\
2\end{array}$ & Yellow & 307 & 164 & $\begin{array}{l}7.86 \\
8.05\end{array}$ & $\begin{array}{l}53.21 \\
62.89\end{array}$ & $\begin{array}{l}4.00 \\
4.00\end{array}$ & $\begin{array}{l}12.0 \\
9.66\end{array}$ \\
\hline & $\mathrm{L}_{2} \mathrm{H}_{4}$ & Yellow & 190 & & & $\begin{array}{l}71.91 \\
69.58 \\
\end{array}$ & $\begin{array}{l}5.61 \\
5.39 \\
\end{array}$ & $\begin{array}{l}10.4 \\
10.3 \\
\end{array}$ \\
\hline 4 & {$\left[\mathrm{Mn}\left(\mathrm{L}_{2} \mathrm{H}_{4}\right)\right] \mathrm{Cl}_{2}$} & cream & 255 & 187 & $\begin{array}{l}8.33 \\
8.61\end{array}$ & $\begin{array}{l}58.18 \\
58.34\end{array}$ & $\begin{array}{l}4.54 \\
4.64\end{array}$ & $\begin{array}{c}8.488 . \\
57\end{array}$ \\
\hline 5 & $\mathrm{~K}_{2}\left[\mathrm{Mn}\left(\mathrm{L}_{2}\right)\right]$ & Dark Yellow & 220 & 152 & $\begin{array}{l}8.29 \\
8.45\end{array}$ & $\begin{array}{l}57.91 \\
49.87\end{array}$ & $\begin{array}{l}3.92 \\
4.01\end{array}$ & $\begin{array}{c}8.447 . \\
46\end{array}$ \\
\hline 6 & $\begin{array}{c}\mathrm{Mn} \\
\left.\left(\mathrm{L}_{2} \mathrm{H}_{4}\right)\right]\left(\mathrm{NO}_{3}\right)_{2} \\
\end{array}$ & Light Yellow & 242 & 135 & $\begin{array}{l}7.71 \\
7.96 \\
\end{array}$ & $\begin{array}{l}53.85 \\
65.03 \\
\end{array}$ & $\begin{array}{l}4.20 \\
4.07 \\
\end{array}$ & $\begin{array}{c}11.78 . \\
54\end{array}$ \\
\hline & $\mathrm{L}_{3} \mathrm{H}_{4}$ & Yellow & 144 & & & $\begin{array}{l}74.22 \\
73.13\end{array}$ & $\begin{array}{l}5.15 \\
5.09\end{array}$ & $\begin{array}{l}9.62 \\
8.75\end{array}$ \\
\hline 7 & {$\left[\mathrm{Mn}\left(\mathrm{L}_{3} \mathrm{H}_{4}\right)\right] \mathrm{Cl}_{2}$} & Light Yellow & 261 & 178 & $\begin{array}{l}7.76 \\
8.32\end{array}$ & $\begin{array}{l}61.01 \\
61.12 \\
\end{array}$ & $\begin{array}{l}4.23 \\
4.49 \\
\end{array}$ & $\begin{array}{c}7.908 . \\
00\end{array}$ \\
\hline 8 & $\mathrm{~K}_{2}\left[\mathrm{Mn}\left(\mathrm{L}_{3}\right)\right]$ & Dark Yellow & 273 & 188 & $\begin{array}{l}7.73 \\
8.09\end{array}$ & $\begin{array}{l}60.75 \\
52.47\end{array}$ & $\begin{array}{l}3.65 \\
3.85\end{array}$ & $\begin{array}{c}7.876 . \\
80\end{array}$ \\
\hline 9 & $\begin{array}{c}{[\mathrm{Mn}} \\
\left.\left(\mathrm{L}_{3} \mathrm{H}_{4}\right)\right]\left(\mathrm{NO}_{3}\right)_{2}\end{array}$ & Yellow & 288 & 147 & $\begin{array}{l}7.22 \\
7.44 \\
\end{array}$ & $\begin{array}{l}56.76 \\
60.96 \\
\end{array}$ & $\begin{array}{l}3.94 \\
3.81 \\
\end{array}$ & $\begin{array}{c}11.07 . \\
92\end{array}$ \\
\hline
\end{tabular}


The electronic spectra of the metal complexes were carried out in DMF. The electronic spectra of Mn(II) complexes (Table 2) showed only one broad band cantered at $13333-15060 \mathrm{~cm}^{-1}$ due to the transition ${ }^{2} \mathrm{~T}_{2} \mathrm{~g} \rightarrow{ }^{2} \mathrm{~T}_{1} \mathrm{~g}$. This band in due to the excition states in system $\mathrm{d}^{5}$ reported octahedral complexes (Nicholls, 1973; El-Tabl et al., 2012; Singh et al., 2013; Al- Shaheen and AlDabagh, 2009) octahedral geometry. In addition, high intensity bands were observed in the ultraviolet region of the spectra and assigned to $\mathrm{C}-\mathrm{T}$ transitions which due to the partial electron density migration from the filled ligands $\pi$-orbital to the empty metal $\pi$-orbitals. The observed CT bands suggested the presence of some $\pi$-character in coordination bonds between the metal ions and the ligand. The magnetic moment of the prepared complexes at room temperature is presented in (Table 2). The results show that $\mathrm{Mn}$ (II) complexes (1.51-2.09) B.M. are all paramagnetic and in good agreement with the low spin octahedral structure (Sadhukhan et al., 2011; Al-Shaheen, 2011).

Table 2: Electronic spectrum $\mathrm{cm}^{-1}$ and magnetic moment data of the complexes

\begin{tabular}{|c|c|c|c|c|}
\hline $\begin{array}{c}\text { No. of } \\
\text { Complexes }\end{array}$ & Formula & $\begin{array}{c}\mu_{\text {eff }} \\
\text { B.M. }\end{array}$ & $v_{1}$ & C.T \\
\hline 1 & {$\left[\mathrm{Mn}\left(\mathrm{L}_{1} \mathrm{H}_{4}\right)\right] \mathrm{Cl}_{2}$} & 1.95 & 13333 & 35087 \\
\hline 2 & $\mathrm{~K}_{2}\left[\mathrm{Mn}\left(\mathrm{L}_{1}\right)\right]$ & 1.51 & 13386 & 40485 \\
\hline 3 & {$\left[\mathrm{Mn}\left(\mathrm{L}_{1} \mathrm{H}_{4}\right)\right]\left(\mathrm{NO}_{3}\right)_{2}$} & 1.76 & 14598 & 33222 \\
\hline 4 & {$\left[\mathrm{Mn}\left(\mathrm{L}_{2} \mathrm{H}_{4}\right)\right] \mathrm{Cl}_{2}$} & 1.51 & 13513 & 33222 \\
\hline 5 & $\mathrm{~K}_{2}\left[\mathrm{Mn}\left(\mathrm{L}_{2}\right)\right]$ & 1.95 & 13477 & 36362 \\
\hline 6 & {$\left[\mathrm{Mn}\left(\mathrm{L}_{2} \mathrm{H}_{4}\right)\right]\left(\mathrm{NO}_{3}\right)_{2}$} & 1.76 & 14598 & 20333 \\
\hline 7 & {$\left[\mathrm{Mn}\left(\mathrm{L}_{3} \mathrm{H}_{4}\right)\right] \mathrm{Cl}_{2}$} & 2.09 & 14992 & 32051 \\
\hline 8 & $\mathrm{~K}_{2}\left[\mathrm{Mn}\left(\mathrm{L}_{3}\right)\right]$ & 1.97 & 15060 & 36496 \\
\hline 9 & {$\left[\mathrm{Mn}\left(\mathrm{L}_{3} \mathrm{H}_{4}\right)\right]\left(\mathrm{NO}_{3}\right)_{2}$} & 2.08 & 13513 & 33222 \\
\hline
\end{tabular}

The coordination sites of the ligands were inferred by infrared spectroscopy, which is considered a useful technique for the IR spectra of the structure of complexes. The infrared data of the main absorption bands of the ligands and the complexes are given in (Table 3 ).

The important infrared spectral of the ligand showed a band at $(3400-3500) \mathrm{cm}^{-1}$ assigned to vOH. For the complexes, the stretching and deformation vibrations of OHgroups were shifted to lower frequency in the $(1,3,4,6,7,9)$ complexes while in the $(2,5,8)$ complexes frequencies did not appear. (Nakamoto, 1997). In the infrared spectra of complexes, the absence of the bands due to $\mathrm{OH}$-stretching and deformation vibrations was attributed to the coordination of the ligand through deprotonanon of the alcoholic hydroxyl groups, compared to their positions in the free ligands spectrum indicating coordination of alcoholic hydroxyl groups through their oxygen atoms. The IR spectrum of the ligand showed a band at (3200-3300) $\mathrm{cm}^{-1}$ assigned to vNH. This band has been shifted to a lower frequency in $(1,3,4,6,7,9)$ complexes formation $(\mathrm{NH})$. This band however did not appear in the $(2,5,8)$ complexes (Taylor et al., 1974). The infrared spectral of the ligand showed a band at (1615-1630) $\mathrm{cm}^{-1}$ assigned to $v \mathrm{C}=\mathrm{N}$. In the complexes, the $\mathrm{C}=\mathrm{N}$ stretching band shows negative shift of about $15-45 \mathrm{~cm}^{-1}$,indicating the involvement of azomethine nitrogen atom in complexes formulation (Taylor et al., 1974; Abd-Elzaher, 2002). The stretching band of the azomethine group was also shifted, suggesting coordination through azomethine nitrogen. The $v$ $\mathrm{C}=\mathrm{O}$ in the ligand appeared at $(1675-1695) \mathrm{cm}^{-1}$; this band shifted to lower frequency in the $(1,3,4,6,7,9)$ complexes while in the $(2,5,8)$ complexes frequencies did not appear.

In addition, the stretching vibration of C-O single bond split into two peaks due to (C-O ) which supports the above suggested coordination of the hydroxyl groups without deprotonation (Sallomi and Al-Shaheen, 1998; Sallomi et al., 2011) (Table 3). The negative shift of about $10-35$ $\mathrm{cm}^{-1}$ in the stretching frequency of carbonyl group suggests coordination through the carbonyl oxygen atom as observed in similar acid hyrazide and hydrazine complexes (Holm et al., 1966; Sallomi,1998). On the other hand, the absence of the stretching band was due to $\mathrm{NH}$ and $\mathrm{C}=\mathrm{O}$ mioety was attributed, as reported for similar cases (Stratton, 1969) to the presence of the 
enol tautomer. The presence of these bands is strong evidence for the enolization deprotonation in alkaline solution. In all complexes of both types, positive shift was observed in the stretching vibration of N-N band. Since the shift is less than $50 \mathrm{~cm}^{-1}$ only one nitrogen atom is involved in bonding (Zhang et al., 2005). In addition to the above mentioned perturbation in infrared spectra, new bands around $470-480 \mathrm{~cm}^{-1}$ and $430-440 \mathrm{~cm}^{-1}$ were observed and tentatively assigned to M-N and M-O stretching modes, respectively (Wilkinson et al., 1987; Nakamoto, 1997).

Table 3: Important IR spectral bands $\left(\mathrm{cm}^{-1}\right)$ of the free ligands and their complexes

\begin{tabular}{|c|c|c|c|c|c|c|c|c|}
\hline No. of Complexes & v O-H & v N-H & v C=N & v C=O & v N-N & v C-O & v M-N & v M-O \\
\hline $\mathrm{L}_{1} \mathrm{H}_{4}$ & 3400 & 3250 & 1630 & 1685 & 1035 & 1200 & - & - \\
\hline 1 & 3300 & 3245 & 1610 & 1675 & 1050 & 1180 & 480 & 440 \\
\hline 2 & - & - & 1595 & - & 1055 & 1175 & 470 & 430 \\
\hline 3 & 3250 & 3240 & 1600 & 1680 & 1050 & 1180 & 480 & 440 \\
\hline $\mathrm{L}_{2} \mathrm{H}_{4}$ & 3410 & 3300 & 1615 & 1695 & 1030 & 1220 & - & - \\
\hline 4 & 3295 & 3280 & 1600 & 1685 & 1045 & 1200 & 475 & 430 \\
\hline 5 & - & - & 1590 & - & 1040 & 1200 & 480 & 440 \\
\hline 6 & 3300 & 3290 & 1585 & 1680 & 1040 & 1190 & 480 & 435 \\
\hline $\mathrm{L}_{3} \mathrm{H}_{4}$ & 3500 & 3200 & 1625 & 1675 & 1020 & 1020 & - & - \\
\hline 7 & 3400 & 3195 & 1600 & 1660 & 1040 & 1180 & 480 & 440 \\
\hline 8 & - & - & 1585 & - & 1050 & 1185 & 480 & 440 \\
\hline 9 & 3400 & 3180 & 1580 & 1640 & 1050 & 1185 & 470 & 435 \\
\hline
\end{tabular}

\section{CONCLUSION}

According to the above studies, it was concluded that all the ligands act as neutral hexadentate in neutral solution giving cationic complexes and coordinating through alcoholic oxygen, carbonyl oxygen and azomethine nitrogen atoms. Basic medium neutral complexes were obtained Fig. (1).

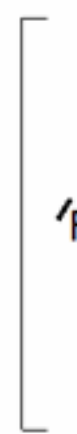

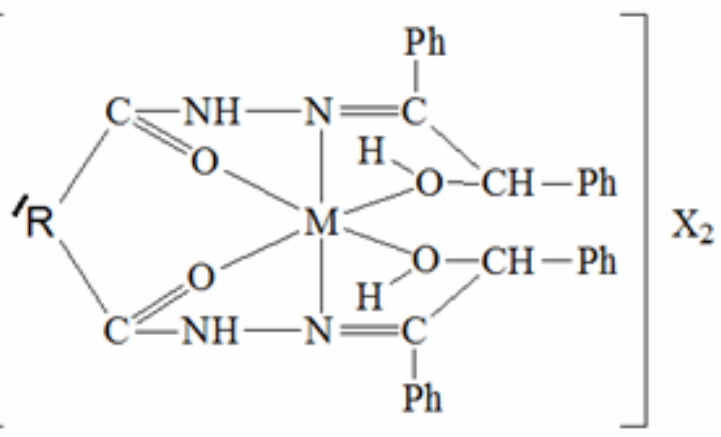

$\left[\mathrm{Mn}\left(\mathrm{LH}_{4}\right)\right] \mathrm{X}_{2}$

$\mathrm{X}=\mathrm{Cl} ; \mathrm{NO}_{3} \cdot \mathrm{L}=\mathrm{L}_{1}, \mathrm{~L}_{2}, \mathrm{~L}_{3}$

R $\mathrm{R}=\mathrm{CH}_{2}, \mathrm{CH}_{2}-\mathrm{CH}_{2}$, ph

(a)

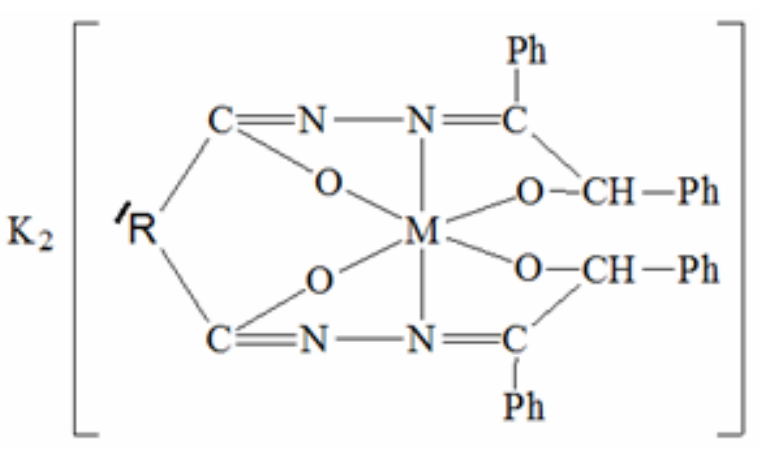

$\mathrm{K}_{2}[\mathrm{Mn}(\mathrm{L})]$

Fig. 1: The proposed structures of complexes

(a) : neutral medium

(b): basic medium 


\section{REFERENCES}

Abd-Elzaher, M.M. (2002). Spectroscopic characterization of some tetradente Schiff base and their complexes with nickel, copper and zinc. J. Chinese Chem. Soc., 48,153.

Al- Shaheen, A.J.; Al-Dabagh, A.M. (2009). Preparation and spectroscopic characterization of some mixed ligand complexes of homodinuclear of $\mathrm{Co}(\mathrm{II}), \mathrm{Ni}(\mathrm{II})$ and $\mathrm{Cu}(\mathrm{II}) .1^{\text {st }}$. Scientific Conference Proceeding Part 5 Chem., Kirkuk University J. Sci. Studies,4,3,33.

Alagesan, M.; Bhuvanesh, N.S.P.; Dharmaraj, N. (2013). Potentially cyotoxic new Copper(II) hydrazone complexes: synthesis, crystal structure and biological properties. J. Chem. Soc., Dalton Trans., 42, 7210 - 7223.

Al-Shaheen, A.J. (2011). Synthesis and fungitoxicity of copper (II) complexes. The $2^{\text {nd }}$ Scientific Conference in Chemistry. Raf. J. Chem. 22-23

Al-Shaheen, A.J.; Al-Bayati, M.R.; Ali, A.M. (2017). Synthesis and characterization some of metal(II) complexes with 2-(6-methoxy naphthalene-2-yl) propionic acid (2-hydroxy benzylidene) hydrazone. International J. Enhenced-Resear., Technol. and Engm., 6(11).

Al-Shaheen, A.J.; Sallomi, I.J.; Al-Sabaawi, S.A. (2012). Preparation, characterization of acid hyrazide Schiff Base complexes of nickel (II) and their biological activity. Iraqi National J. Chem., 48.

Al-Shaheen, A.J.; Sallomi, I.J.; Al-Sabaawi, S.A. (2013). Some new schiff base complexes of copper (II) and their biological screening. Kirkuk Uni. J. Sci. Studies, 8(2), 48-58.

Baker, W.; Haksar, C.N.; Mcomie, J.F.W. (1950). Fluorescent reagents, acyl chlorides and acyl hydrazides. J. Chem. Soc., 170.

Bernhardt, P.V.; Wilson, G.J.; Sharpe, P.C.; Kalinowski, D.S.; Richardson, D.R. (2008). Tuning the antiproliferative activity of biologically active iron chelators: characterization of the coordination chemistry of 2-acetylpyridine and 2-benzoylpyridine hydrazone ligands. $J$. Biol. Inorg. Chem., 13, 107-119.

Chohan, Z.H.; Farooq, M.A.; Iqbal, M.S. (2000). Synthesis, characterization and biological properties of anions on bivalent transition metal Co (II) and $\mathrm{Ni}$ (II) complexes with acylhydrazine-derived ONO donor Schiff bases. Metal-Based Drugs., 7, 133-139.

Ciobanu, A.; Zalaru, F.; Albinescu, D.; Zalaru, C. (2006). Coordination compound of Cu(II) and $\mathrm{Ni}$ (II) with Schiff bases derived from formylmenthone and o-, m-,p- toluidine. Southern Brazil J., 7(8), 95-104.

Despaigne, A.R.; Dasilva, J.G.; Docarmo, A.C.; Piro, O.E.; Castellano, E.E.; Beraldo, H. (2009). Copper(II) and zinc(II)complexes with 2-benzoyl pyridine-methyl hydrazone. J. Mol. Struct., 920, 97-102.

El-Table, A.S.; Shakdofa, M.M.E.; Shakdofa, A.M.E. (2012). Metal complexes of N'-(2-hydroxy5phenyldiazenyl)benzylidene isonicotino hydrazide. synthesis, spectroscopic characterization and anti bacterial activity. J. Serb. Chem. Soc.,77,1-29.

Feng, Y.; Wang, C.; Zhao, Y.; Li, J.; Liao, D.; Yan, S.; Wang, Q. (2009). Out- of- plane. Dimeric $\mathrm{Mn}(\mathrm{III})$ quadridentate Schiff-base complexes: synthesis, structure and magnetic properties. Inorganic Chem. Acta, 362(10), 3563-3568.

Geary, W.J. (1971). The use of conductivity measurement in organic solvents for the characterization of coordination compounds. Coord. Chem. Rev., 7, 81-122.

Holm, R.H.; Evere, J.R.; Chakravorty, R.S. (1966). Metal complexes of schiff bases and 3 ketoimines. Inorganic Chem., 7, 83

Jang, Y.J.; Lee, U.; Koo, B.K. (2005). Synthesis and crystal structures of Mn(II), Co(II), Ni(II), $\mathrm{Cu}(\mathrm{II})$, and $\mathrm{Zn}(\mathrm{II})$ metal complexes with NNO functionalized ligand. Bull. Korean. Soc., 26(6), 925-929.

Nakamoto, K. (1997)." Infrared and Raman 7 Spectra of Inorganic and Coordination Compound". $5^{\text {th }}$ ed., Part B, John Wiley and Sons, Incorporation.

Nicholls, D. (1973). "The Chemistry of Iron, Cobalt, Nickel". Pergamo Press. $1^{\text {st }}$ ed. 
Sadhukhan, D.; Ray, A.; Pilet, G.; Rizzoli, C.; Rosair, G.M.; Gomez-Garcia, C.J.; Signorella, S.; Bellu, S.; Mitra, S. (2011). Weak interaction modulating the dimensionality in superamolecular architectures in three new nickel(II) hydrazone complexes, magnetostructural correlation, and catalytic potential for epoxidation of alkenes under phase transfer conditions. Inorg. Chem., 50, 8326-8339.

Sallomi, I.J.; Shaheen, A.J. (1998). Complexes of cobalt (II), nickel(II) and copper(II) with orthoand para- phenylene diamine derivatives. Polyhedron, 17, 1429.

Sallomi, I.J.; Al-Shaheen, A.J. (1994). Complexes of hydrazide Schiff bases. Transition, Met. Chem., 19, 275.

Sallomi, I.J.; Al-Shaheen, A.J.; Al-Sabaawi, S.A. (2011). Acid hydrazide Schiff base complexes of cobalt (II) and their biological activity. Raf. J. Sci., 2nd Sci-Conference in Chemistry 2223 November, 389-400.

Sallomi, I.J.; Al-Shaheen, A.J.; Al-Sabaawi, S.A. (2011). Acid hydrazide Schiff base complexes of cobalt (II) and their biological activity. Raf. J. Sci., 2nd Sci-Conference in Chemistry 2223 November, 389-400.

Sathyadevi, P.; Krishnamoorthy, P.; Algesan, M.; Thanigaimani, K.; Muthiah, P.T.; Dharmaraj, N. (2012). Synthesis crystal structure, electrochemistry and studies on protein binding, antioxidant and biocidal activities of $\mathrm{Ni}(\mathrm{II})$ and $\mathrm{Co}(\mathrm{II})$ hydrazone complexes. Polyhedron, 31, 294-306.

Saydam, S.; Alkan, C. (2001). Synthesis and characterization of a new thiazole Schiff base of 5bromo-2-hydroxybenzylidene -2- aminobenzothiazole and its Complexes with $\mathrm{Co}(\mathrm{II})$, $\mathrm{Cu}(\mathrm{II})$ and $\mathrm{Ni}(\mathrm{II})$. Polish J. Chem., 75, 29-33.

Singh, V.P.; Singh, P. (2013). Synthesis, spectral characterization and thermal studies of Co(II), $\mathrm{Ni}(\mathrm{II}), \mathrm{Cu}(\mathrm{II})$, and $\mathrm{Zn}(\mathrm{II})$ complexes with 2-amino benzoic acid and 2-hydroxy benzoic acid thiophene 2-methylene hydrazide. J. Mol. Struct., 1035,363-370.

Singh, V.P.; Singh, S.; Singh, D.P.; Singh, P.; Tiwari, K.; Mishra, M.; Butcher, R.J. (2013). Synthesis, spectral and single x-ray diffraction studies on $\mathrm{Co}(\mathrm{II}), \mathrm{Ni}(\mathrm{II}), \mathrm{Cu}(\mathrm{II})$, and $\mathrm{Zn}(\mathrm{II})$ complexes with o-amino acetophenone benzoyl hydrazone. Polyhedron. 56 ,71-81.

Sone, K.; Fukuda, Y. (1987). Inorganic Thermochromism: Inorganic Chemistry.

Stratton, W.J.; Reng, M.F.; Drug, R.F. (1969). Metal complexes with azine ligand hydrolysis and template synthesis in the iron (III)-2-pyridinaldazine system. Inorganic Chem. Acta., 3, 97.

Suresh, M.S.; Prakash, V. (2011). Preparation, characterization and antibacterial studies of chelates of Schiff base derived from 4-aminoantipyrinevanillin and o-phen- Ylene diamine. International J. Cur. Research, 3,68.

Taylor, M.K.; Trotter, K.D.; Reglinski, J.; Berlouis, L.E.A.; patronKennedy, R.D. (1974). Iron (III) complexes of pentadentate ligands. Inorganic Chem. Acta., 8, 191.

Wageih, G.H.; Moawaad, N. (2001). Synthesis, characterization and antimicrobial activity of $\mathrm{Co}(\mathrm{II}), \mathrm{Ni}$ (II) and $\mathrm{Cu}$ (II) with new asymmetrical Schiff base. Transition Metal Chem. 26(6), 644.

Wilkinson, G.; Gillard, R.D.; McCleverty, J.A. (1987). "Comprehensive Coordination Chemistry". Pergamon Press, Great Britain, $1184 \mathrm{p}$.

Zhang, L.; Lu, X.; Zhaug, Q.; Chen, C.; Kang, B. (2005). Coordination modes of diphosphines in silver(I)-di-phosphine complexes mediated by 2,4,6-tri(2- pyridy 1)-1,3,5triazine(tptz). Transition Metal Chem., 30(1), 76. 